УДК 94:349.412(497.1)"1921"

342.4:332.282(497.1)"1921"

DOI https://doi.org/10.31212/tokovi.2021.3.mil.11-36

Оригинални научни рад

Примљен: 17. 10. 2021.

Прихваћен: 12. 11. 2021.

Srđan MILOŠEVIĆ

Institute for Recent History of Serbia, Belgrade srdjan.milosevic@inis.bg.ac.rs

\title{
Land Property Regime According to the Vidovdan Constitution and the Agrarian Question in the Kingdom of Serbs, Croats and Slovenes*
}

\begin{abstract}
The paper discusses the attitudes of political parties on land property regimes in the context of the agrarian issue, and dynamics of the debate on this matter in the Constitutional Committee and in the Constituent National Assembly of the Kingdom of Serbs, Croats and Slovenes. The very notion of "agrarian question" concerns specifically small peasant landholdings in the process of development of capitalism. This question was raised in the context of the debate on socio-economic problems that were invited by, and eventually, introduced into the Constitution of the Kingdom of Serbs, Croats and Slovenes (Vidovdan Constitution, 1921) under the pressure of progressive opposition parties and parts of the ruling political organizations.
\end{abstract}

KEY WoRdS: Vidovdan (St. Vitus Day) Constitution, Kingdom of Serbs, Croats and Slovenes, socio-economic provisions, agrarian issue, peasantry

\section{Introduction}

In February 1921, the representatives of the political parties in the Constitutional Committee of the Constituent National Assembly of the Kingdom of the Serbs, Croats and Slovenes debated the draft articles ded-

This paper was written as a result of the work at the Institute for Recent History of Serbia, funded by the Serbian Ministry of Education, Science and Technological Development, through the Agreement on Realization and Funding of Scientific Research NIO in 2021 no. 451-03-9/2021-14/200016 of February 5, 2021. 
icated to the agrarian policy. In an exchange during the debate, the representative of the Agrarians, Mihailo Avramović, praised ostentatiously his party: "You see how useful the presence of the Agrarian party is in this Committee. It first pointed out this issue (i.e. agrarian question - S. M.)". Voja Veljković from the Democratic Party responded immediately: "We brought up the agrarian issue, not you." Mihajlo Avramović, not giving up, replied: "No, it was emphasized firstly by the Agrarian party". To this exchange yet another participant contributed - namely "a voice from the communists" - claiming: "We pointed it out first." However, the dispute over the agrarian question would wait for an epilogue and a constitutional solution of the agrarian question until June 1921. The contemporary stenographer, only a few months later, captured the stormy atmosphere in the Assembly that characterized the adoption of the most important articles of the Constitution related to this issue: "The Agrarians and Communists are protesting loudly, pounding on the benches with great noise... Loud applause in the center". ${ }^{2}$

As a matter of fact, the agrarian question raised itself. Political parties obviously all agreed on the need to solve it. But the answers they gave to that question caused the abovementioned stormy atmosphere once the related articles of the Constitution had been finally formulated.

In the state created by the unification of Serbia, Montenegro and the South Slavs from Austria-Hungary in 1918 this issue was among the most urgent ones. ${ }^{3}$ The notion "agrarian question" relates to the complex matter concerning the status of the petty peasantry in the process of development of capitalism, primarily in the view of land ownership in the countryside. ${ }^{4}$ The agrarian policy is not, of course, limited to this sole is-

1 ІХ. седница - 12. фебруара 1921, Рад Уставног одбора Уставотворне скупштине Краљевине Срба, Хрвата и Словенаца, І., Дебата у начелу о нацрту Устава, (Београд: Народна самоуправа, б. г.), 88.

2 XLIV. редовни састанак - 2. јуна 1921, Стенографске белешке Уставотворне скупштине Краљевине Срба, Хрвата и Словенаца, II књига, (од XXXVIII до XLVIII редовног састанка), (Београд: Државна штампарија Краљевине Срба, Хрвата и Словенаца, 1921), 17.

3 This particular issue hasn't been much discussed in historiography. Only one article dedicated to the agrarian question within the context of constitutional debate in 1921 has been published so far, yet providing only partial and "panoramic" insight into the problem. See: Љубица Кандић, „Аграрно питање и Устав СXС из 1921“, Анали Правног факултета у Београду 16, бр. 2 (1968), 265-278. Also Александар Фира, Видовдански устав, (Београд: САНУ, 2011), 168-178, contains a few pages on this topic too.

4 More precisely, „the agrarian question is a term coined by the German Marxist Karl Kautsky thatrefers to the process of transition of relations of production in agriculture 
sue. However, the first Constitution of the Kingdom of Serbs, Croats and Slovenes from 1921 actually deals disproportionally - although not exclusively - with this sole aspect of the agrarian policy, only superficially treating the other aspects.

The new state has been conveniently described in a scholarly article as a "museum of agrarian structures". ${ }^{5}$ Within the territorial scope of the Kingdom of SCS the most various regimes of property in land coexisted, ranging from all sorts of modern private property (large estates, middle sized farms and petty parcels), followed by the plethora of land regimes having originated from the central-European or the Ottoman feudal system, ending with the colonate in Dalmatia, having survived, mutatis mutandis, from the antiquity. ${ }^{6}$ In the debate during the session of the Constitutional Committee in May 1921, Lazar Marković, one of the leading representatives of the Radical Party plainly admitted that it was unknown what types of land property relations existed in the country at that moment. He justified a generalized wording of an article in the Draft of the Constitution, openly declaring: "We could not (...) examine all those various agrarian relations which exist in Old Serbia, which exist in Dalmatia, which also exist in Bosnia and Herzegovina, to examine all these various relations in detail, and to enumerate them accurately".7

Aimed at abolishing all remnants of feudal relations, relations similar to feudal, and of large land estates in the Kingdom of SCS in February 1919 the agrarian reform had been announced. It had been regulated by the Interim Decree on the Preparation of the Agrarian Reform. ${ }^{8}$ The consti-

from pre-capitalist to capitalist mode of production; its role and significance for overall capitalist development of the economy and the fate of small peasantry in this process." Ramana Murthy, "Introduction" in: The Agrarian Question. A Reader, ed. Ramana Murthy, (New York, London: Routledge, 2021), 11.

5 Doreen Warriner, „Urban Thinkers and Paesant Policy in Yugoslavia, 1918-1959”, The Slavonic and East European Review 38/1959, 60.

6 For an overview of the property to land regimes existent at the time of the Yugoslav unification on the territory of the new state see: Milivoje Erić, Agrarna reforma $u$ Jugoslaviji 1918-1941. god., (Sarajevo: Veselin Masleša, 1958).

$7 \quad$ XLV. sednica - 23. maj 1921, Rad Ustavnog odbora Ustavotvorne skupštine Kraljevine Srba, Hrvata i Slovenaca, IV., Debata u pojedinostima o nacrtu Ustava io amandmanima, Sednica XLV. do XLV, (Beograd: Narodna samouprava, 1921), 85.

8 On the manner of passing the Preliminary Provisions for Land Reform and their application, in addition to the aforementioned study by Milivoj Erić, see also: Богдан Лекић, Аграрна реформа у Југославији 1918-1941, (Београд: Службени лист, 2002); Срђан Милошевић, „Аграрна политика у Југославији (1945-1953)“, (докторска дисертација, Универзитет у Београду, Филозофски факултет, Одељење за историју, 2016), 25-35. 
tutional provisions adopted two and a half years later, in June 1921, followed the outlines established by this document.

Historiography has already detected the palliative character of the agrarian reform in the Kingdom, as well as its sedating effect due to the fear of revolutionary movements. ${ }^{9}$ A most instructive testimony about the character of the reform was the 1929 report that Otto Franges, the Minister of Agriculture, submitted to King Alexander, emphasizing that the reform was "a political, unavoidable necessity." Namely, "returning from Bolshevik Russia, prisoners of war and Green Cadres in the mountains have been so imbued with revolutionary ideas regarding private property, especially land ownership... that some sort safety valve had to be opened for them (my emphasis). This could only be done with a promise that a land reform would divide large landholdings." ${ }^{\prime 10}$

This paper will not present a detailed comparative analysis of the relevant provisions contained in the constitutions of other countries, adopted roughly at the same time. However, it should be at least mentioned that the relatively extensive introducing of the agrarian policy program may be considered as a somewhat distinctive feature of the Vidovdan Constitution. For example, in the Weimar Constitution of 1919, this matter was present in an elaborate form only in Article 155, which provided that "the distribution and use of the soil shall be controlled by the state in such a manner as to prevent abuse and to promote the object of assuring to every German a healthful habitation and to all German families, especially those with many children, homesteads for living and working that are suitable to their needs... Landed property the acquisition of which is necessary for the satisfaction of the demand for dwellings, for the promotion of colonization and reclamation, or for the improvement of agriculture may be expropriated. Entailments shall be abolished. The cultivation and use of the soil shall be the duty of its owner toward the community. An increase in the value of land which accrues without the application of labor or capital to the property shall inure to the benefit of all." ${ }^{\prime 1}$ In Czechoslovakia and Hungary, this issue did not find a place in the constitutional texts at all, while the Polish constitution contained the following, also ex-

$9 \quad$ Mijo Mirković, Ekonomska historija Jugoslavije, (Zagreb: Informator, 1968), 205; Erić, Agrarna reforma u Jugoslaviji, 276-278.

10 Arhiv Jugoslavije (Archives of Yugoslavia-AJ),Zbirka Vojislava Jovanovića Maramboa (335), kutija 19, (Ministar poljoprivrede Oto Frangeš - Kralju Aleksandru, 28. januar 1929. godina).

11 Howard Lee McBain, Lindsay Rogers, The New Constitutions of Europe, (New York: Doubleday, 1922), 206. 
tensive provision: "Land, as one of the most important factors of the existence of the nation and the state, may not be the subject of unrestricted transfer (commerce). Statutes will define the right of the state to buy up land against the will of the owners, and to regulate the transfer of land, applying the principle that the agrarian organization of the Republic of Poland should be based on agricultural units capable of regular production and forming private property."12

Questions of land ownership and, in a broader sense, of agrarian policy, were not unique to the Vidovdan Constitution, but the situation in the Kingdom of SCS was undoubtedly a motivation to pay closer attention to them. This was certainly the case considering the country had, compared to the states mentioned above, the most complex land ownership structure. On the other hand, the share of agricultural rural population in these states was different, but in most cases very high. They accounted for $78 \%$ in Romania, $63 \%$ in Poland, 55\% in Hungary and only $34 \%{ }^{13}$ in Czechoslovakia. In the Kingdom of SCS, this was roughly $80 \%{ }^{14}$

The high share of the rural (agricultural) population in a number of new states also affected the legal system in these countries, though not exclusively through constitutional arrangements. ${ }^{15}$ As for the Kingdom of SCS, the vast majority of bourgeois political parties and politically active intellectuals agreed that this was a "peasant state", which was not only a statement of fact, but also a value judgement and ideological creed meant to laud the peasantry. Such an ideological platform was important for deciding on the constitutional solutions of land ownership relations and for proving who is the greater "friend of the peasants" among the parties. ${ }^{16}$

12 Ibid., 419-420.

13 Sarahelen Thompson, "Agrarian Reform in Eastern Europe Following World War I: Motives and Outcomes", American Journal of Agricultural Economics 3/1993, 840.

14 Статистички годишњак Краљевине Југославије за 1929, књ. 1, (Београд, 1929), 86-88.

15 George Papuashvili, „Post-World War I comparative constitutional developments in Central and Eastern Europe", International Journal of Constitutional Law 1/2017, 137-172, https://doi.org/10.1093/icon/mox011

16 Warriner, “Urban thinkers”, 59-81; Гаћеша, „Аграрни програми грађанских политичких партија“, 125-171; Srđan Milošević, „The Agrarian Reform - A 'Divine Thing'. Ideological aspects of the agrarian reform in the Kingdom of Serbs, Croats, and Slovenes/Yugoslavia", Transforming Rural Societies. Agrarian Property and Agrarianism in the Nineteenth and Twentieh Centuries, eds Dietmar Müller, Angela Harre, (Insbruk, Wien, Bozen: Studien Verlag, 2011), 47-62; Срђан Милошевић, ,'Jа теби певам, сељаче, и кличем' - сарадници Нове Европе о селу и сељаштву”, Нова Европа, збрник радова, ур. Марко Недић, Весна Матовић, (Београд: Институт за књижевност и уметност, 2010), 171-207. 


\section{Basic Property Provisions in the Vidovdan Constitution}

The Vidovdan Constitution deals with agrarian issues in its socio-economic rights section. The early draft of the Constitution of the Kingdom of Serbs, Croats and Slovenes did not include this section. ${ }^{17}$ However, the social rights of citizens and the duties of the state were pushed to the foreground by the Communists, Socialists, the Peasant Party and the Yugoslav Club. This subject turned out to be the second most discussed in debates rivaled only by the national question and the status of the historical provinces that joined the common state. ${ }^{18}$ Finally, during March-April 1921, the Constitutional Committee included in the Draft Constitution a section entitled "Social and Economic Rights", making it a third point in the Constitution's text. In the final version, the section included a total of 22 articles, which makes for $15.5 \%$ of all the articles of the Constitution. This was a clear admission, especially in the period following the great turmoil, that the state should play an important social role. Legal regulations in the socio-economic domain proved Karl Renner's point, who claimed that it was "the time of sudden transition of bourgeois to social law". ${ }^{19}$

It is well established in scholarship that the inclusion of this section in the Constitution was strongly influenced by the 1919 Weimar Constitution. ${ }^{20}$ The introduction of social and economic provisions of this extent and content was a novelty in the legal system of any region that formed the SCS Kingdom. Namely, until then, none of the states that existed on the territory of the future Yugoslav state had guaranteed such extensive social and economic rights to its population. ${ }^{21}$

17 The first draft of the Constitution was presented to the National Assembly on January 25, 1921: VI. редовни састанак - 25. јануара 1921. године, Стенографске белешке Уставотворне скупштине Краљевине Срба, Хрвата и Словенаца, I Књига, (Од I претходног до XXXVII редовног састанка), (Београд: Државна штампарија Краљевине Срба, Хрвата и Словенаца, 1921), 2-9.

18 Слободан Јовановић, Уставно право Краљевине Срба, Хрвата и Словенаца, (Београд: Издавачка књижарница Геце Кона, 1924), 40.

19 Karl Rener, Socijalna funkcija pravnih instituta, Prilog kritici građanskog prava, (Beograd, 1997), 22, as cited in: Ljubomir Petrović, „Socijalna politika u Kraljevini Jugoslaviji: Bilans jednog neuspeha“, Istorija 20. veka 2/2011, 119.

20 Even Slobodan Jovanović noted that "an entire section numbering 23 articles on social and economic provisions was subsequently added to the Draft Constitution, mainly following the model of the new German constitution." Јовановић, Уставно право, 37. See also: Љубица Кандић, „Социјално економске одредбе Видовданског устава и Вајмарски устав", Зборник радова Правног факултета у Новом Саду III/1969, 321-337.

21 Ivan Kosnica, "Social Rights in the First Yugoslavia (1918-1941): Tradition, Model and Deviations", New Studies in History and Law, eds Norbert Varga, David A. Frenkel, 
One tendency in particular should be noted as a distinctive feature of the Vidovdan Constitution regarding socio-economic rights: in the original draft, which was debated before the socio-economic provisions were added, guarantees of property rights were placed in the civil rights section. ${ }^{22}$ In the final draft, this right was included among the social and economic provisions, although the constitution, naturally, kept the section on civil rights. This was in the spirit of the tendency to view property from its social function perspective, which significantly diluted its inviolability.

Namely, in the section "Basic civil rights and duties", the original draft of the Constitution stated the following: "Property is guaranteed. The content, scope and restrictions of private property are determined by law. Feudal relations are abolished."23 Therefore, in principle, the government's Draft Constitution already paved the way for restricting private property even before the subsequent introduction of socio-economic provisions. However, in the final draft, as we mentioned, the article on property was placed among the social and economic provisions. This was done at the suggestion of Mihailo Avramović, who explained the proposal saying that "the question of property (...) is an important issue of social and economic nature," which the Committee accepted without objection. ${ }^{24}$ However, this "mild" announcement of state encroachment on property rights was unacceptable to vocal opponents of the idea of the sanctity of private property in the opposition, who ultimately did not support this article.

At the Constitutional Committee meetings, the idea of fundamental change in understanding of private property was voiced on several occasions, and this was emphasized by all political groups. ${ }^{25}$ Apart from the Communists, who were still a non-systemic organization (but as the third strongest party in the Assembly had to be taken into account), the most convincing supporters of radical restriction of private property were the Agrarrians. One of their leaders and the representative in the Constitutional Committee, Mihailo Avramović, argued that "today's right to property is no longer what it was for Roman lawmakers. According to Avram-

(Athens: Institute for Education and Research, 2019), 91-97.

22 Фира, Видовдански устав, 98.

23 VI. редовни састанак - 25. јануара 1921. године, Стенографске белешке Уставотворне скупштине, I, 3.

24 XVI. sednica - 22. februara 1921, Rad Ustavnog odbora Ustavotvorne skupštine Kraljevine Srba, Hrvata i Slovenaca, II., Debata u pojedinostima o nacrtu Ustava, Odeljak I-VI. (član 1-56.) - Sednica XIII. do XXV, (Zagreb: Tiskara Jugoslavenske štampe, b. g.), 50.

25 On the political party grouping and their basic views on the agrarian question, see: Кандић, „Аграрно питање“, 268-272. 
ović "property is a social phenomenon, which contains social purposes and tasks, and it can only be tolerated" as long as it performs them. ${ }^{26}$ Private property in the form of large landholdings had its opponents among the Democrats as well, and one of the prominent ones was Milutin Jakšić. To his mind, large estates were the product of plunder, "and if something was stolen 100 years ago, it does not become property - plunder is not a titulus for creating property rights." ${ }^{27}$

The Radicals, and especially the Yugoslav Muslim Organization (YMO), stood at the other end of the dispute. Miroslav Spalajković, one of the leading members of the Radical Party, emphasized that the right to property can only be "properly regulated (in terms of objects), or strongly limited (in terms of the subject)". He argued that this right was still "the main stimulus, the main psychological lever for labor and production" and that "private property and the family are institutions which originate in the natural and normal instincts of men." ${ }^{28}$ As a matter of fact, there was a sharp dichotomy in the Radical Party regarding the ongoing relativization of the private property and its inviolability in favor of the state's social responsibilities. The party took into account several factors: a) the need to satisfy the peasants' hunger for land (especially that of the veterans of war), b) not to completely alienate the large landholders who lost their property in the land reform and to whom the Radicals were therefore willing to recognize the right to compensation and c) to firmly guarantee private property after the implemented reforms, which should not jeopardize large estates too much, them being economically more viable. There was a noticeable divide in the party on this issue, but a more conservative approach dominated among the leadership, with the exception of the Bosnian Radicals led by Milan Srškić. ${ }^{29}$

The government saw socio-economic policies as a concession to opposition political groups. Explaining the introduction of the socio-eco-

26 Рад Уставног одбора Уставотворне скупштине Краљевине Срба, Хрвата и Словенаца, I, 23.

27 XXXV. седница - 18. марта 1921, Рад Уставног одбора Уставотворне скупштине Краљевине Срба, Хрвата и Словенаца, III., Дебата у појединостима о нацрту Устава, Одељак III. нови (члан 1.- 16. и 20.), Одељак IV. по предлогу Ужег одбора (члан 48.) и Оодељак VII. - XI. (члан 57.- 86.), Седница XXVI.-XL, (Загреб: Тискара Југославенске штампе, б. г.), 102.

28 XXVIII редовни састанак - 11. и 12. маја 1921. године, Стенографске белешке Уставотворне скупштине, I Књига, 4.

29 Кандић, „Аграрно питање“, 267-268; Никола Гаћеша, „Аграрни програми грађанских политичких партија у Југославији између два светска рата“, Радови из аграрне историје и демографије, (Нови Сад: Матица српска, 1995), 125-171. 
nomic rights section, Marko Trifković, a Minister for the Constituent Assembly, pointed out that the original government proposal was criticized for lacking socio-economic provisions and that suggestions were constantly made to address these issues in the Constitution. Thus the government, according to Trifković, wanting the Constitution to be an expression of the agreement of all parties, benevolently assumed "that the proposals were submitted with the intention of making the Constitution as complete, clear and precise as possible". That is why it "went out its way to accommodate and accept those proposals." ${ }^{30}$

When the final draft of the Constitution was adopted, it was a compromise of two opposing approaches, with Article 37 stating: "Property is guaranteed. Property entails obligations. Its use must not be to the detriment of the whole. The content, scope and restrictions of private property are determined by law. Expropriation of private property in the general interest is permitted by law, with fair compensation." ${ }^{11}$ In the end, the Constitution elaborated far more on the matter of possible restrictions on private property than the original draft. According to Democrat Juraj Demetrović, the Constitutional Committee vice-president, the wording of the property rights article acknowledged that "property had no longer the meaning it used to have, but that the social moment had entered the very notion of property and in a way transformed it." 32 Finally, this alteration became a matter of doctrine. Slobodan Jovanović wrote in his textbook of constitutional law that the provision on property was a "compromise between the individualistic and socialist understanding of property", i.e. that it represents "an amalgam of personal rights and social functions." ${ }^{33}$

But not even this elaboration satisfied the radical tendencies among the opposition. Naturally, the communists and socialists could not vote for the Constitution, regardless of its social provisions, which they considered insufficient, like the entire constitutional design. The few Republicans also decided not to support it, as did the Agrarian Club, the most numerous bourgeois opposition group in the Constituent National

30 XIV. Redovni sastanak - 14. aprila 1921, Стенографске белешке Уставотворне скупштине, I Књига, 7.

31 Устав Краљевине Срба, Хрвата и Словенаца, (Београд: Издавачка књижарница Геце Кона, 1921).

32 XXXIX. редовни састанак - 27. маја 1921, Стенографске белешке Уставотворне скупштине, II Књига, 5. For more details on Demetrović's address, see: Фира, Видовдански устав, 169.

33 Јовановић, Уставно право, 452. 
Assembly, who were also displeased both with the Constitution itself and especially its section on social and economic rights.

As paradoxical as it may seem, with the political calculations and promises the government made to the beys, ${ }^{34}$ the Constitution got the support of the Yugoslav Muslim Organization, which was strongly against the provision on "socializing" the functions of private property. Defended in principle, it is clear that such an attitude of the YMO was the result of the interests of the Bosnian beys to protect large estates from agrarian reform. In that sense, the position of Šemsudin Sarajlić, speaking on behalf of this party, was paradigmatic: Criticizing the possibility of expropriation "for the common interest", he rejected this formulation, and reiterated that the YMO is "on the side of property, i.e. that a person cannot have his property expropriated except in cases of serious government necessity." According to the YMO, only in the case of such a "government necessity", and not in the name of an undefined "public interest", could expropriation be allowed. ${ }^{35}$

The question of property was crucial for agrarian policy measures as well, and that is why it received somewhat more attention. After all, views of property best reflect fundamental political and economic tendencies in society. In addition to the provisions directly related to agriculture and the peasantry, which are the focus of this paper, other articles from the "Social and economic provisions" section should be briefly mentioned: state guarantee to provide equal access to training for commercial occupations in accordance with the student's inclinations and interests, to provide professional education and arrange for financial assistance for talented poor children (Article 22); protection of workers, especially women and minors, from occupations harmful to their health (Article 23); protecting intellectual rights (Article 24); freedom of contract "as long as it does not operate against the public interest" (Article 25); the government had the right and duty to "intervene in commercial relations of citizens in the spirit of justice and elimination of social contradictions" (Article 26); an extensive guarantee of public health care (especially for women and children), including free medical care, medication and other material for poor citizens (Article 27); the government's commitment to legally regulate workers' insurance "in case of injury, illness,

34 The government had promised to meet the demands of the beys to the greatest extent possible in terms of compensation.

35 XLII. редовни састанак - 30. маја 1921, Стенографске белешке Уставотворне скупштине, II Књига, 20. 
unemployment, incapacity, old age and death" (Article 31), and similarly regulate the position of sailors (Article 34); guarantee of special care for war invalids, the fallen, as well as for their families (Article 32); guarantee of workers' right to organize (Article 33); prohibition of usury (Article 38); the law on inheritance tax was supposed to provide the participation of the state in inheritance, taking into account the degree of kinship and the value of the inheritance (Article 39). ${ }^{36}$

The final article in the socio-economic section authorized the creation of a special agency for drafting social and economic legislation - the Economic Council (Article 44). The formation of this agency was first proposed by the Republican representative Jovan Đonović in a Constitutional Committee debate. He envisioned this agency as having authority to "instruct the government on conducting economic policy, and give the legislature elements for introducing social regulations." ${ }^{37}$ However, the Constitution only provided the general outline for the establishment of this body, leaving the law to define its establishment, composition and powers. This institution was also borrowed from the Weimar Constitution, in which its function was elaborated in detail, but it also had a role in the lawmaking procedure regarding socio-economic regulations. ${ }^{38}$ However, such a body was not created while the Vidovdan Constitution was in force, just as many provisions from this section of the Constitution remained unfulfilled. ${ }^{39}$

\section{Land Ownership Provisions Relevant to the Position of the Peasantry}

Land ownership in a broader sense (including forested land), directly or indirectly, is the subject of several articles of the Vidovdan Con-

36 Устав Краљевине Срба, Хрвата и Словенаца, 9-13; Фира, Видовдански устав, 169.

37 VI. седница - 9. фебруара 1921, Рад Уставног одбора Уставотворне Скупштине, I, 47.

38 In connection with the Economic Council's role in socio-economic legislation discussed above, there is the following provision from the Weimar Constitution (Article 165, paragraph 4): "The National Ministry shall, before proposing drafts of politico-social and politico-economic bills of fundamental importance, submit them to the Economic Council of the Reich for consideration. The Economic Council of the Reich shall itself have the right to initiate drafts of such bills. If the National Ministry fails to assent, it shall nevertheless present the draft to the Reichstag accompanied by an expression of its views. The Economic Council of the Reich may designate one of its members to appear before the Reichstag in behalf of the proposal". McBain, Rogers, New Constitutions of Europe, 208-209.

39 See: Petrović, „Socijalna politika u Kraljevini Jugoslaviji“, 119. 
stitution. Article 38 prescribes the abolition of fideicommissum, but does not clearly define the subsequent fate of such properties, so this article is beyond the scope of this paper. Somewhat more relevant is Article 30, which prescribed that agricultural ensurance would be legally regulated. But even this article is not elaborated and is only indirectly related to peasant land ownership.

Article 41 of the Constitution provides for the expropriation of large forest estates, in favor of the government. The only real right that the article gave to the peasants regarding the expropriated forest estates is the right of use, i.e. that "farmers and persons occasionally engaged in agriculture are allowed logging for timber and firewood, and grazing livestock, in state owned and municipal forests," under the conditions determined by law. ${ }^{40}$

Among the most important agrarian provisions of the Vidovdan Constitution are those that provided for the abolition of the remnants of feudal relations (Article 42): "Feudal relations are considered legally abolished on the day of liberation from foreign rule. If injustices have been committed before that point in time by resolving feudal relations or turning them into private law relations, reparation must be made possible by law. The serfs (chifchis), as well as farmers who cultivate the land in serf-like relations, are proclaimed free owners of the land they farm, without paying any restitution, and the land is to be titled to their name." This article was a summary of the program already in force in the Kingdom, contained in the Interim Decree on the Preparation of the Agrarian Reform of February 25, 1919. In a sense, from the perspective of the peasantry. it was the only essentially far-reaching socio-economic provision related to agriculture, since it unequivocally abolished feudal relations. ${ }^{41}$

The Agrarian Club's amendment to this article insisted that "the land belongs to those who work it," without any compensation to former owners. In addition, by enumerating serfs, chifchis, coloni, and "similar statuses," the Agrarians believed they are minimizing the risk ofthe restrictive (narrow) meaning of a notion "feudal relationship" the abolishing of which this article guaranteed. Finally, the Agrarians' demanded the distribution of government land to peasants and aiding those landlords who were left "without means of subsistence" in the process of severing feudal

40 Устав Краљевине Срба, Хрвата и Словенаца, 12.

41 Ferdo Čulinović, Državnopravna historija jugoslavenskih zemalja XIX. i XX. vijeka, Druga knjiga: Srbija - Crna Gora - Makedonija - Jugoslavija 1918-1945, (Zagreb: Školska knjiga, 1954), 262. 
relations. ${ }^{42}$ The Socialists also submitted the amendment which stipulated that the land was "the property of the entire people", but only those who cultivated it could "hold it". The Socialists' draft explicitly mentions former tenants (beglučari), chifchis and wage laborers as beneficiaries of the abolition of feudal relations, which was also an arbitrary classification. In the same amendment, the Socialists demanded that the government commits to various types of assistance to farmers. ${ }^{43}$ As for the Communists, by that time, they had been completely suppressed, and the government had not even considered their amendments. Their activity was reduced to exposing what they understood as tendencies to sidestep the social program, even in its reduced form. ${ }^{44}$ Eventually, this article was received with virtually no changes to the proposed government draft. ${ }^{45}$

The abolition of existing and prohibition of establishing new feudal relations, as already mentioned, was foreseen by the original government draft, but this matter was elaborated in the final text. The additional guarantees to the beneficiaries of these provisions were granted, although such guarantees already existed in other legal documents. However, the groups proposing more radical approach to resolving the agrarian question stressed that the two-year implementation of the Preliminary Provisions demonstrated that stronger guarantees were needed to make sure the land reform would genuinely accommodate the peasantry. This was why those groups demanded the said guarantees to be enshrined in the Constitution.

The need to provide comprehensive constitutional guarantees to former serfs was first emphasized by the socialist representative in the Constitutional Committee, Nedeljko Divac. Already in the general debate, he pointed out that not only the general provision, but also "the direction for resolving this question must be set in the Constitution. The clear directions for resolving other parts of the agrarian question should be set in the Constitution as well. As for land reform in its entirety, the Constitution should guide legislation in such a manner that land should belong to those who work it". ${ }^{46}$ The Republican representative Jovan Đonović went

\footnotetext{
42 LIV. sednica - 23. maja 1921, Rad Ustavnog odbora Ustavotvorne skupštine, IV, 82.

43 Ibid.

44 Фира, Видовдански устав, 175-176.

45 XLV. sednica - 5. aprila 1921, Rad Ustavnog odbora Ustavotvorne skupštine, IV, 39.

46 IV. седница - 4. фебруар 1921, Рад Уставног одбора Уставотворне скупштине, I, 19.
} 
a step further, emphasizing that, just as it had abolished feudal relations, the state can "place limits on the influence and power of capital." 47

The government representative in the Committee, the Radical Milan Srškić, was also dissatisfied with the government's draft, seeing in it a compromise where there should not have been one, as he put it. His view was that the "healthy principle" of abolishing feudalism was "drastically inverted" in the very next sentence of the Constitutional provision. He especially criticized the announcement that "injustices" caused by "resolving feudal relations or turning them into private-law relations" would be legally amended. This provision referred to the application of the Safer order according to which the serfs in Bosnia were removed from the land they cultivated. Since this was issued during the Austro-Hungarian administration, the authorities of the time ensured "that all these verdicts have a legal appearance, both formally and materially. When such a verdict issued twenty or thirty years ago, for which all evidence was lost, comes before a court, clearly no court will be able to overturn it, but will confirm it in favor of the spahis, not the peasants." ${ }^{\prime 8}$

The most explicit were the Communists, who demanded not only the abolition of feudal relations. According to their proposal, the entire land of feudal lords, but also of landowners and religious organizations should be distributed to the peasants, and provided with farming equipment. Although the Communists, understandably, principally supported the nationalization of all the landholdings, they believed that small and middle peasants should be allowed to keep their possession "until they themselves, through experimentation, reached the conclusion that they do not need private ownership of the land, because it has lost the function that it had in capitalist society." This, however, would be possible only in socialism. ${ }^{49}$ As Sima Marković pointed out, "Communists are in principle against private property", but that does not mean that "even when working people take power into their own hands (...) private property will disappear, that it will vanish." 50

For their part, the YMO representatives tried to defend the position of the beys in every way, so they claimed that "serf relations were not entirely feudal relations" so that this issue needed to be approached with more tact, and not by simple expropriation. The Muslim Club rep-

47 VI. седница - 9. фебруар 1921, Рад Уставног одбора, I, 47.

48 LIV. sednica - 23. maja 1921, Rad Ustavnog odbora, IV, 82.

49 VIII. седница - 11. фебруар 1921, Рад Уставног одбора, I, 81.

50 Рад Уставног одбора, III, 101. 
resentative Fehim Kurbegović warned of sectarianism towards Muslim landowners. He pointed out that there their number was not "a thousand, or two or three thousands" but "hundreds of thousands" (counting family members) and that state policy, by resolving the agrarian question, "creates proletariat and misery on the other side." He also warned of demands that "beys should not be given land, even if they wanted to work it." ${ }^{\prime 1}$ The argument that the simple division of land to former serfs would create new problems of poverty among the bey families was mostly put forward by those who represented the interests of this class in the committee and the assembly.

The notion of "serf-like relations" which was deliberately left in that form, as Juraj Demetrović explained on behalf of the Constitutional Committee, came under criticism, leaving it to the law to determine what constitutes these types of relations. Demetrović cited the Dalmatian colonate as an example. This late antique system implied a very wide range of relations - from those very similar to serfdom to land leasing as a private law relationship. If, therefore, the colonate were included as a whole as a relationship that is terminated in terms of Article 42 of the Constitution, situations would arise where a private law relationship would be terminated in favor of the tenant who would receive the land for free, which was considered unacceptable. ${ }^{52}$

However, as the supporters of the radical solution of the agrarian question argued, the phrase "serfdom-like relations" was a sign that the government intended to avoid its duties towards peasants who cultivate another's land without having their own. Namely, there were fears that, without a clear enumeration of those to whom the land provision refers, the broadness of the phrase "serfdom-like relations" would actually lead to very few of those relations being considered "similar". On the other hand, more conservative representatives, such as the radical Momčilo Ivanić, were concerned that the phrase was too broad, and that it may cover even sharecropping in Serbia itself, which according to Ivanić, would cause "unrest and disorder" in parts of the country where there is virtually no disputed agrarian relations to be resolved." ${ }^{53}$ Sreten Vukosavljević of the Democratic Party also expressed fears about the ambiguity of

51 Х. седница - 14. фебруара 1921, Рад Уставног одбора, I, 124.

52 XXXIX. редовни састанак - 27. маја 1921, Стенографске белешке Уставотворне скупштине, II књига, 6.

53 XLIII. редовни састанак - 31. маја и 1. јуна 1921, Стенографске белешке Уставотворне скупштине, II књига, 15. 
that formulation, saying that there could be "disloyal interpretation of this position." 54

The fears expressed by the opposition were probably better grounded, but the ruling majority also had an explanation that was not unconvincing. Namely, as Lazar Marković explained, the formulation remained broad "so that all those relations which are really equal in nature and in their essence to serf relations (...) would be covered by these constitutional regulations." In essence, Marković claimed that when the Constitution was discussed, the real situation regarding the types of agrarian relations was not even known, which is why it was "left to those who enforce these constitutional regulations to determine... which relations will be considered." 55

Much more vague was Article 43 of the Constitution, which left the possibility for the distribution of other large land estates(not of a feudal character) to the peasants who worked them. Article 43 of the Constitution provided as follows: "The expropriation of large landholdings and their distribution to those who cultivate the land shall be regulated by law. The law will also determine what compensation will be given for expropriated property. No compensation will be given for large holdings that belonged to members of former foreign dynasties and for those given to individuals by the foreign authorities." ${ }^{56}$

Here we notice a departure from the Interim Decree. This act stated that possessions obtained for serving foreign dynasties will be confiscated without compensation. ${ }^{57}$ However, the Constitution left a more flexible provision in that regard, which prescribed only that no monetary compensation be given for such property, but not that such property would necessarily be confiscated, as prescribed by theearlier decree. Also, the issue of who is entitled to compensation for the expropriated property of feudal origin was not unambiguously resolved in theIntreim Decree, although it was claimed that the compensation was "guaranteed by the government". The Constitution, on the other hand, stipulates that the government is obliged to pay that compensation..$^{58}$ In general, the constitutional provisions were less radical than the Preliminary Provisions, so

54 XLI. redovni sastanak - 28. maja 1921, Стенографске белешке Уставотворне скупштине, II књига, 10.

55 XLV. sednica - 23. maja 1921, Rad Ustavnog odbora, IV, 84-85.

56 Устав Краљевине Срба, Хрвата и Словенаца, 13.

57 Prethodne odredbe za pripremu agrarne reforme, Службене новине Краљевства Срба, Хрвата и Словенаца, бр. 11, 27. 2.1919.

58 Кандић, „Аграрано питање“, 268. 
the leader of Slovenian farmers, Etbin Kristan, rebuked the government: "Apart from feudal estates, there are all sorts of landlords, whom you certainly do not dare touch." ${ }^{59}$

Article 43 of the Constitution also regulates some issues related to colonization (which is beyond the scope of this paper), and then the last paragraph prescribes the following: "The law will determine the maximum amount of land in possession, and the minimum amount which cannot be alienated." In this case, the proposed solution differed significantly from the one eventually adopted. Namely, the government's draft stated the following: "The law will determine the smallest area of a farmer's land and cases in which it cannot be divided among the heirs or alienated in any other way." ${ }^{\prime 60}$ The Yugoslav Club representative in the Constitutional Committee, Janko Šimrak, was the first to oppose such a formulation, demanding that the maximum amount of land in one's possession also be determined. ${ }^{61}$ Miloš Moskovljević spoke in the same vein, reminding everyone that such a suggestion could be found in the Draft Constitution proposed by the Agrarian Club on whose behalf he spoke. He stated that in Serbia before the war the land was progressively falling "into the hands of lawyers" and that without limiting the maximum amount of land in possession, the class of rural proletariat would inevitably be created. ${ }^{62}$ Democrat Milutin Jakšić suggested that the expropriation should cover not only large, but also medium-sized property, since, in his opinion, this would be necessary if land was to be given to everyone who needed it, especially war veterans. ${ }^{63}$

The government majority representative, Radical Žarko Miladinović, pointed out that that limiting the maximum amount of land would be unnecessary, claiming that it would happen in practice all the same, "because when the little man gets land, when he can work the land and reap the fruits of his labor, he will grow stronger. It will be him who works the land, and the landlord will have no workers, no one to work for him, and will be forced to either sell it or ask for help from the peasant, for a large part of the income." ${ }^{64}$ After the debate in the Assembly, it was decided to

59 XIV. редовни састанак - 11. априла 1921, Стенографске белешке Уставотворне скупштине, I Књига, 12.

60 XLV. sednica - 5. aprila 1921, Rad Ustavnog odbora, IV, 43.

61 Ibid.

62 Ibid, 47. See also: Момчило Исић, Милош Московљевић у посланичкој клупи, (Свилеува: Друштво за изучавање историје Свилеуве, 2019).

63 XLV. sednica - 5. aprila 1921, Rad Ustavnog odbora, IV, 45.

64 Ibid., 48. 
return the last paragraph of Article 43 to the Constitutional Committee for rewriting. The Minister for the Constituent Assembly informed the Committee about that, noting that, although no one spoke in the Assembly in that sense, there were objections that were personally communicated to him against the provision that guaranteed the minimum landholdings and especially about the last paragraph of Article 43 on the impossibility of dividing minimum landholdings among heirs. ${ }^{65}$

Contrary to what was the intention of the Government, the fact that this Article was returned to the Committee for reconsideration prompted the opposition deputies to suggest not only keeping the minimum holdings provision, but also to introduce the provision on the allowed maximum amount of land. Namely, Uroš Stajić from the Agrarian Club, agreed on the removal of the inheritance restriction from the article that defined the agrarian minimum, but reintroduced the idea of the agrarian maximum. ${ }^{66}$ Among the representatives of the government majority in the Constitutional Committee Milorad Vujičić believed that no provisions on maximum or minimum landholdings, or expropriation, should be introduced. ${ }^{67}$ His colleague Lazar Marković remarked that from the legal point of view, it does not matter whether there will be such provisions or not. Probably thinking of provisions on restricting private property (Article 37), as well as the expropriation provision (Article 43), he pointed out that the lawmakers can subsequently determine maximum or minimum landholdings, or both. For Marković, therefore, defining the maximum is "just a bluff and pulling the wool over people's eyes, tricking them into believing that the question of large properties has been resolved." ${ }^{68}$

Jovan Đonović disagreed with this position, emphasizing that it was an important provision, having in mind the systemic interpretation of the Constitution: "As soon as we start about limiting large properties, it means that there is a current of ideas, which points to limiting the creation of large landholdings in the countryside in the future... The current of ideas suggests limiting large landholdings and all those who come after us they have to take that into account." ${ }^{69}$

While the majority in the Constitutional Committee easily accepted the removal of the provision that forbade dividing minimum landhold-

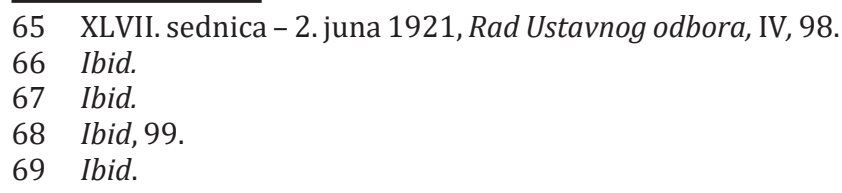


ings, during the debate it became clear that the last paragraph of Article 43 would not be removed, which was the intention of Minister Trifković and government representatives in the Committee. Beside keeping that provision, the majority of the speakers demanded that a provision on maximum landholdings also be included in that paragraph. Minister Trifković stated that he could accept the obligation to legally determine the maximum landholdings, but that the provision on the minimum is unacceptable since would drive down peasant creditworthiness. This argument of the Minister for the Constituent Assembly was not accepted, after which Trifković stated with resignation: "Well, gentlemen, when you do not want to give in, let me give in. What else can I do, so as not to argue further, I would suggest that this paragraph reads as follows: 'The law will determine the maximum amount of land in possession, as well as cases in which the minimum amount of land cannot be alienated." With the approval of the members of the committee who advocated such a solution, the Constitutional Committee unanimously accepted Trifkovićs proposal, which proceeded to go before the Constituent Assembly in that form, and then into the Constitution.

However, the general feeling regarding this and most other provisions in the section on social and economic rights was best described by the Bosnian representative Marko Gaković, who left the Agrarian Club and formed a group in the assembly with several other dissidents: ${ }^{70}$ "As far as I understood the speakers, no one from the majority or the opposition praised this paragraph, but everyone said it's not any good. And I ask you, what is the point of accepting something today if we say it's not good." Alluding to the fact that the government has reached an agreement with the beys on compensation, Gaković ironically said that compensation to the beys "cannot be justified by social justice" because "there are much more people poorer than beys who need social assistance." In the end, Gaković also complained about "our Serbian brothers" who were not ready to "support" the fight of Serbian deputies from Bosnia against compensation, but on the contrary, "defend the beys." ${ }^{11}$

However, one of the Peasant Alliance leaders, Dragoljub Jovanović, a leading experts on the agrarian issue in his time, had a more moderate

70 Драга В. Мастиловић, Српска елита из Босне и Херцеговине у политичком животу Краљевине СХС/Југославије, (докторска дисертација, Универзитет у Београду, Филозофски факултет, Одељење за историју, 2013), 315.

71 XLIV. редовни састанак - 2. јуна 1921, Стенографске белешке Уставотворне скупштине, II књига, 11. 
view then some of his comrades-in-arms. According to his understanding, "the Vidovdan Constitution (June 28, 1921), even if it was adopted with the help of bey and Jamiat votes, still meant the victory of progressive aspirations on the agrarian front. It allows the expropriation of private property in the general interest; abolishes the fideicommissum; transfers ownership of forests to the government; abolishes serfdom and chifchi relations; designs expropriation of large estates and their division to agrarian stakeholders; - and therefore gives most of what was promised to the people in the tumultuous autumn of 1918." ${ }^{2}$ That this assessment was more optimistic than realistic is proven by the fact that, although the agrarian question was not resolved until 1941, the subsequent Octroic September Constitution of 1931 did not contain any of the mentioned solutions.

\section{Conclusion}

The section on social and economic rights was included in the government's Draft Constitution in April 1921, since there were many parties in the National Assembly that had such provisions in their programs and their drafts of the Constitution. One of the questions that attracted attention and was prominent both in those drafts and in the government draft debate was the issue of land ownership, especially in the context of abolishing feudal relations and the distribution of large landholdings. Even among members of the majority parties in parliament, there were those who made bold demands regarding the division of land to the peasants, especially among the Democrats.

Wanting to provide the widest possible support for its Draft Constitution, the government introduced a number of socio-economic provisions, as a concession to the progressively oriented opposition and to similar views in their own ranks. The government could eventually hope that with certain concessions, it would get the support of the bourgeois part of the opposition, that is, from the Agrarian Club, the Yugoslav Club and the Republicans. The Socialists could less be relied upon in any combination to support the Draft Constitution, and the Communists not at all. However, it was certainly necessary to erode their influence, at least by meeting the social program of the bourgeois parties. In the end, support for the government's draft of the Constitution came from the sharpest opponents of the socio-economic provisions on land ownership - the Yugoslav Muslim Organization. The government's efforts to secure their

72 Dragoljub Jovanović, Agrarna politika, (Beograd: Narodna misao, 1930), 268. 
support actually destroyed the possibility of gaining the support of other opposition parties, as the government undertook to pay the beys significant compensation for the expropriated land, which all opposition parties with progressive social programs strongly opposed.

Of the opposition's suggestions, the government only accepted the idea to include socio-economic provisions in the Constitution, but determined the "degree" of their presence, their content and their far-reaching nature, with no regard for the opposition's amendments. Opposition parties believed that the government's solutions would at the very least enable very conservative interpretations. They feared that significant, or even less radical social changes would certainly not occur precisely because the government would be very restrictive in interpreting guaranteed rights. Subsequent experience confirmed such doubts of the opposition. It seems that the government parties believed they would manage to keep the majority in the Assembly for a longer period of time and would manage to solve the agrarian question in their own way - with very moderate reforms, and not radical steps. That is why they found it important that the norms in the Constitution on this issue be flexible enough to be interpreted in a more conservative way.

\section{Summary}

Provisions aimed at solving the agrarian question are present in the Constitution of the Kingdom of Serbs, Croats and Slovenes from 1921 in several extensive articles. This is the most notable presence of such norms compared to any other constitution adopted immediately after the First World War in Central and South-Eastern Europe. The present paper delves into the provisions regulating the property in land and their significance for the peasantry in the Kingdom SCS. The abolition of the existing feudal and similar relations, as well as the partition of large estates both the feudal and the capitalist ones - were the topics heatedly debated during the sessions of the Constitutional Committee and of the Constituent National Assembly. These debates are the main source for this paper. The systematics of the Constitution (the articles that regulated this matter were part of the section on social and economic rights) reflected the understanding that the issue of property, especially in the context of resolving the agrarian question, was an imminently social issue. This approach was adopted under the strong pressure from the progressive opposition parties - Agrarians, Socialists and, to some extent and mostly indirectly, 
the Communists. However, similar views were harbored by many Democrats and by some Radicals, the two parties that were the backbone of the parliamentary majority, which catalyzed the process of adopting the progressive agenda. The constitutional solution to the agrarian question represented a compromise among the views upheld by the majority and those upheld by the opposition, but leaving a room for more conservative application of the provisions compared to seemingly progressive guarantees enshrined in the Constitution.

\section{Sources and Literature}

- $\quad$ Arhiv Jugoslavije. Zbirka Vojislava Jovanovića Maramboa (335), 19.

- $\quad$ Rad Ustavnog odbora Ustavotvorne skupštine Kraljevine Srba, Hrvata i Slovenaca, I., Debata u načelu o nacrtu Ustava. Beograd: Narodna samouprava, b. g. (cyrillic)

- $\quad$ Rad Ustavnog odbora Ustavotvorne skupštine Kraljevine Srba, Hrvata i Slovenaca, II., Debata u pojedinostima o nacrtu Ustava Odeljak I-VI. (Član 1-56.) Sednica XIII. do XXV. Zagreb: Tiskara Jugoslavenske štampe, b. g.

- $\quad$ Rad Ustavnog odbora Ustavotvorne skupštine Kraljevine Srba, Hrvata i Slovenaca, III., Debata u pojedinostima o nacrtu Ustava, Odeljak III. novi (član 1.-16. i20.), odeljak IV. po predlogu užeg odbora (član 48.) i odeljak VII.-XI. (član 57.86.) Sednica XXVI.-XL. Zagreb: Tiskara Jugoslavenske štampe, b. g. (cyrillic)

- $\quad$ Rad Ustavnog odbora Ustavotvorne skupštine Kraljevine Srba, Hrvata i Slovenaca, IV., Debata u pojedinostima o nacrtu Ustava i o amandmanima, Sednica XLI. do XLV. Beograd: Štamparija Narodna samouprava, 1921.

- $\quad$ Statistički godišnjak Kraljevine Jugoslavije za 1929, knj. 1. Beograd, 1929.

- Stenografske beleške Ustavotvorne skupštine Kraljevine Srba, Hrvata i Slovenaca, I Knjiga, (Od I prethodnog do XXXVII redovnog sastanka). Beograd: Državna štamparija Kraljevine Srba, Hrvata i Slovenaca, 1921. (cyrillic)

- Stenografske beleške Ustavotvorne skupštine Kraljevine Srba, Hrvata i Slovenaca, II knjiga, (od XXXVIII do XLVIII redovnog sastanka). Beograd: Državna štamparija Kraljevine Srba, Hrvata i Slovenaca, 1921. (cyrillic)

- Ustav Kraljevine Srba, Hrvata i Slovenaca, Beograd: Izdavačka knjižarnica Gece Kona, 1921. (cyrillic)

- Čulinović, Ferdo. Državnopravna historija jugoslavenskih zemalja XIX. i XX. vijeka, Druga knjiga: Srbija - Crna Gora - Makedonija - Jugoslavija 19181945. Zagreb: Školska knjiga, 1954.

- Erić, Milivoje. Agrarna reforma u Jugoslaviji 1918-1941. god. Sarajevo: Veselin Masleša, 1958.

- $\quad$ Fira, Aleksandar. Vidovdanski ustav. Beograd: SANU, 2011. (cyrillic) 
- Gaćeša, Nikola. „Agrarni programi građanskih političkih partija u Jugoslaviji između dva svetska rata". Radovi iz agrarne istorije i demografije, 125-171. Novi Sad: Matica srpska, 1995.

- Isić, Momčilo. Miloš Moskovljević u poslaničkoj klupi. Svileuva: Društvo za izučavanje istorije Svileuve, 2019. (cyrillic)

- Jovanović, Slobodan. Ustavno pravo Kraljevine Srba, Hrvata i Slovenaca. Beograd: Izdavačka knjižarnica Gece Kona, 1924. (cyrillic)

- Kandić, Ljubica. „Agrarno pitanje i Ustav SHSiz1921“. Anali Pravnog fakulteta u Beogradu 16, br. 2 (1968), 265-278.

- Kandić, Ljubica. „Socijalno ekonomske odredbe Vidovdanskog ustava i Vajmarski ustav“. Zbornik radova Pravnog fakulteta u Novom Sadu III/1969, 321-337.

- Kosnica, Ivan. "Social Rights in the First Yugoslavia (1918-1941): Tradition, Model and Deviations". New Studies in History and Law, eds Norbert Varga, David A. Frenkel, 91-97. Athens: Institute for Education and Research, 2019.

- $\quad$ Lekić, Bogdan. Agrarna reforma u Jugoslaviji 1918-1941. Beograd: Službeni list, 2002. (cyrillic)

- $\quad$ Mastilović, Draga V. „Srpska elita iz Bosne i Hercegovine u političkom životu Kraljevine SHS/Jugoslavije“. Doktorska disertacija, Univerzitet u Beogradu, Filozofski fakultet, Odeljenje za istoriju, 2013. (cyrillic)

- McBain, Howard Lee, Lindsay Rogers. New Constitutions of Europe. New York: Doubleday, 1922.

- Milošević, Srđan. „Agrarna politika u Jugoslaviji (1945-1953)“. Doktorska disertacija, Univerzitet u Beogradu, Filozofski fakultet, Odeljenje za istoriju, 2016. (cyrillic)

- $\quad$ Milošević, Srđan. „'Ja tebi pevam, seljače, i kličem’ - saradnici Nove Evrope o selu i seljaštvu". Nova Evropa, zbornik radova, ur. Marko Nedić, Vesna Matović, 171-207. Beograd: Institut za književnost i umetnost, 2010.

- Milošević, Srđan. „The Agrarian Reform - A 'Divine Thing'. Ideological aspects of the agrarian reform in the Kingdom of Serbs, Croats, and Slovenes / Yugoslavia". Transforming Rural Societies. Agrarian Property and Agrarianism in the Nineteenth and Twentieh Centuries, eds Dietmar Müller, Angela Harre, 47-62. Insbruk, Wien, Bozen: Studien Verlag, 2011.

- $\quad$ Mirković, Mijo. Ekonomska historija Jugoslavije. Zagreb: Informator, 1968.

- Ramana Murthy, "Introduction". In: The Agrarian Question. A Reader, ed. Ramana Murthy. New York, London: Routledge, 2021.

- Papuashvili, George. „Post-World War I comparative constitutional developments in Central and Eastern Europe". International Journal of Constitutional Law 1/2017, 137-172. doi: 10.1093/icon/mox011

- Petrović, Ljubomir. „Socijalna politika u Kraljevini Jugoslaviji: Bilans jednog neuspeha“. Istorija 20. veka 2/2011, 119-132. doi: 10.29362/ist20veka.2011.2.pet.119-132 
- $\quad$ Thompson, Sarahelen. "Agrarian Reform in Eastern Europe Following World War I: Motives and Outcomes". American Journal of Agricultural Economics 3/1993, 840-844. doi: 10.2307/1243605

- Warriner, Doreen. „Urban Thinkers and Peasant Policy in Yugoslavia, 19181959". The Slavonic and East European Review 38/1959, 59-81. 


\title{
Резиме
}

\author{
Срђан Милошевић
}

\section{Земљишна својина према Видовданском уставу и аграрно питање у Краљевини Срба, Хрвата и Словенаца}

\begin{abstract}
АПстрАКт: У раду се разматрају ставови политичких партија и динамика расправе у Уставном одбору и у Уставотворној скупштини Краљевине Срба, Хрвата и Словенаца о земљишној својини у контексту аграрног питања. Ово питање тиче се специфично ситног сељачког земљишног поседа у процесу развоја капитализма. Проблем је био разматран у контексту социјално-економских решења која су унета у Устав Краљевине Срба, Хрвата и Словенаца (Видовдански устав, 1921) под притиском прогресивних опозиционих и делова владајућих странака.

КљУчнЕ РЕчи: Видовдански устав, Краљевина СХС, социјално-економске одредбе, аграрно питање, сељаштво
\end{abstract}

Одредбе посвећене решењу аграрног питања присутне су у Уставу Краљевине Срба, Хрвата и Словенаца из 1921. године, у неколико опширних чланова, више него у било ком од устава донетих непосредно после завршетка Првог светског рата у централној и југоисточној Европи. У овом раду представљене су одредбе које су се односиле на земљишну својину и њихов значај за сељаштво у Краљевини. Разрешење затечених „кметских и кметству сличних односа“, као и деоба великих поседа феудалног и капиталистичког карактера биле су теме о којима се детаљно расправљало на седницама Уставног одбора и Уставотворне народне скупштине. Те дебате су главни извор овог рада, који прати аргументације различитих страна у тим дебатама. Кроз предложена владина решења, њихова оспоравања од стране опозиције и противаргументе владиних странака сагледава се смисао усвојених решења. Систематика чланова Устава који су регулисали поменуту материју (њихово смештање у одељак о социјалним и економским правима) рефлектовала је схватање да је питање својине, нарочито у контексту решавања аграрног питања, иманентно социјалног карактера. Ово схватање је било усвојено под снажним притиском пре свега опозиционих партија, као и захваљујући јаким 
струјама са сличним гледиштима првенствено међу демократама, али и међу радикалима, као партијама које су чиниле окосницу владине већине. Усвојена решења су представљала компромис који је више одсликавао становишта владиних странака, остављајући могућност за конзервативнија решења од оних која су Уставом наизглед била гарантована. 